\title{
Special issue of the International Journal of Human Resource Management: Digitization and the transformation of human resource management
}

Jeroen Meijerink, Mark Boons, Anne Keegan \& Janet Marler

To cite this article: Jeroen Meijerink, Mark Boons, Anne Keegan \& Janet Marler (2018):

Special issue of the International Journal of Human Resource Management: Digitization and the transformation of human resource management, The International Journal of Human Resource Management, DOI: $10.1080 / 09585192.2018 .1503845$

To link to this article: https://doi.org/10.1080/09585192.2018.1503845

(c) 2018 The Author(s). Published by Informa

UK Limited, trading as Taylor \& Francis Group.

Published online: 02 Nov 2018.

Submit your article to this journal $\pi$

Џll Article views: 946

View Crossmark data ¿ 


\title{
Special issue of the International Journal of Human Resource Management: Digitization and the transformation of human resource management
}

\author{
Jeroen Meijerink ${ }^{a}$, Mark Boons ${ }^{b}$, Anne Keegan $^{c}$ and Janet Marler ${ }^{d}$ \\ ${ }^{a}$ Human Resource Management Department, University of Twente, Enschede, \\ The Netherlands; ${ }^{b}$ Department of Technology and Operations Management, Erasmus \\ University Rotterdam, Rotterdam, The Netherlands; 'Human Resource Management and \\ Employment Relations Department, University College Dublin, Dublin, Ireland; \\ ${ }^{\mathrm{d}}$ School of Business, State University of New York at Albany, Albany, NY, USA
}

\section{Focus and aim of the special issue}

The purpose of this special issue is to catalyze research on the implications of digitization of work for human resource management (HRM) theory and practice. With regard to digitization, we distinguish three, related, recent developments, namely the increasing use by organizations of (1) sensors \& (big) data collection, (2) analytics \& artificial intelligence and (3) algorithms, robots \& automation of work processes (Brynjolfsson \& McAfee, 2014; Davenport \& Kirby, 2016). Collectively, these developments are expected to have important implications for the nature, structure and conditions of work with work activities being increasingly sourced through online platforms and, as a consequence, for HRM. While these changes have attracted attention from various academic disciplines, these developments have so far attracted only modest attention from HRM scholars despite the potential to disrupt the traditional practice of HRM in organizations. Acknowledging the long tradition within the HRM discipline to study the interfaces between technology and HRM (Bondarouk, Parry, \& Furtmueller, 2017; Hannon, Jelf, \& Brandes, 1996; Marler \& Fisher, 2013; Meijerink, Bondarouk, \& Maatman, 2013; Ruël, Bondarouk, \& Looise, 2004; Strohmeier, 2009), this special issue aims to contribute to theory and practice by extending our understanding, and our empirical awareness, of how more advanced forms of digitization transform the HRM function and affect how people work and are managed in the digital/platform economy. 


\section{Research topics that would fit this special issue}

This special issue welcomes papers that examine the direct and/or indirect impact of recent developments in digitization on the HRM function (in online platform environments). Research topics that relate to the direct impact of digitization on HRM activities include the application of the Internet of Things (IoT) and smart devices for HRM purposes, such as the automation of training practices, collection of employee performance data and real-time workforce planning (Strohmeier, in press) supported by increasing use of sensors and utilization of (big) data these enable. Direct alterations in HRM also involve the use of artificial intelligence and algorithms for automating feedback provision and allocating tasks to employees without human interference - also called algorithmic HR management (Chen, Mislove, \& Wilson, 2015). In turn, the (big) data which these digital applications generate can be used for HR analytics (Marler \& Boudreau, 2017). Although these digital developments may make HRM more efficient and effective, they also raise concerns about worker privacy, the marginalization of HRM professionals, worker resistance and perceptions of injustice.

HRM is indirectly impacted by how digitization developments may affect the future of work. The expectation is that digital technologies will change the organization and nature of work (Colbert, Yee, \& George, 2016; Habraken \& Bondarouk, 2017). An emerging phenomenon here are Smart Industries (also referred to as Industry 4.0) which require workers to adopt new skill sets needed to work in jobs that emerge or change as a result of increased datafication, robotization and automation (Habraken \& Bondarouk, 2017). The notion that automation is eliminating and/or changing jobs suggests that HRM activities could be increasingly important in helping employees to remain employable (Brynjolfsson \& McAfee, 2014).

However, other changes which are indirect in nature may influence the HRM function in ways that make it less important. Change brought about by the rise of online labor platforms may fundamentally change work relationships by crowdsourcing jobs to independent contractors or so-called gig workers that are 'hired' on-demand (Boons, Stam, \& Barkema, 2015; Nakatsu, Grossman, \& Iacovou, 2014). Online platforms implement HRM practices to maintain 'relationships' with their workers, and to motivate, develop and retain the quality of their on-demand workforce. In comparison to 'traditional' organization, these practices are primarily designed and implemented by marketing specialists, computer specialists, customers and data analysts. These developments can marginalize 'traditional' organizationally based HRM professionals. The HRM practices of online labor platforms are also reported to compromise gig 
workers' wellbeing and welfare (Coyle, 2017; Fieseler, Bucher, \& Hoffmann, in press; Kuhn \& Maleki, 2017).

Finally, the organizations that are currently considering how to transform their HRM function in light of these developments in digitization are also pro-actively influencing public policy. In a digitized world were work is crowdsourced to freelancers via online platforms, many aspects of current governmental policy with regard to labor laws and regulations have become obsolete or inadequate. Consequently, platform firms that are implementing new HRM practices are challenged to think more proactively about the future of work (relations) and labor laws.

\section{Suggested research questions}

It is against the backdrop of the advances in digitization that we invite researchers to investigate how current and recent developments in the digitization of work are transforming and impacting the role of HRM professionals and the nature of HRM practices in the digital platform economy. As such, authors will be asked to submit studies that not only make a theoretical contribution but also add to practitioners' capacity to understand the implications of advanced forms of digitization for HRM policies, practices and processes as well as for their own roles in this new landscape. Researchers from various disciplines - such as (electronic) HRM, employment and labor relations, organizational behavior, information systems, entrepreneurship, etc. - are invited to submit their work to this special issue. Questions of potential interest include, but are not limited to:

- How does the use of algorithms and artificial intelligence (by online platform firms) affect HRM outcomes? Through what mechanisms and under what conditions are these outcomes realized?

- How is adoption of advanced HR technologies changing the nature of HRM jobs and structures in organizations?

- What are intended and unintended outcomes of the use of HR analytics at organizational and individual levels of analysis? What key contingencies must be identified in order to realize intended outcomes for platform firms as well as their users (i.e. worker and customers)?

- Which competences do HR specialists need in order to create value out of big (employee) data and HR analytics? Does this provide HR professionals a seat at the strategic table? How does this impact on HR professional values? 
- What are the ethical implications of increasing the collection and use of individual data to manage employee relationships, careers and behaviors?

- What are the implications of developments in smart industries, smart services and IT-enabled business models for employees' jobs, competences and careers? How can HRM support employees to reap the benefits of, and be augmented by, artificial intelligence, robots, or IoT, rather than be substituted by these digital technologies?

- Which HRM practices help to attract, develop and motivate independent contractors and on-demand gig workers? Through what conceptual mechanisms do these HRM practices bring about desired outcomes?

- Are current theories used by HRM researchers (e.g. resource-based view, social exchange theory, attribution theory) to explain outcomes of HRM systems valid and sufficient when applied to the platform economy and gig workers who are non-employees?

- Who is responsible for implementing HRM activities associated with the employment of gig workers: customers, algorithms, workers themselves? Which knowledge, skills and abilities do these (new) HRM actors need to effectively implement HRM?

- What HR roles do customers play in a digitized HRM context including those associated with hiring, performance management, wellbeing, and rewards (of gig workers)? What motivates customers to appraise gig worker performance? Are customers involved in wellbeing initiatives aimed at gig workers?

- Do the HRM activities of online labor platforms mainly favor these platform firms at the expense of employee well-being? What do labor unions and HR professionals need to do to protect workers' rights in the platform economy?

- How does public policy in the domain of employment affect, and how is it affected by, the digitization of work, rise of online labor platforms and the transformation of HRM practices? How do policy considerations impact $\mathrm{HR}$ professionals with regard to the digitization of work and the transformation HRM practices?

\section{Submission guidelines and process}

Manuscripts should be submitted online using the International Journal of Human Resource Management ScholarOne Manuscript website (https://mc.manuscriptcentral.com/rijh) by April 30, 2019.

The format of the submissions should follow the guidelines of the International Journal of Human Resource Management, which can be 
found on the following website: https://www.tandfonline.com/action/ authorSubmission?journalCode=rijh20\&page $=$ instructions .

All manuscripts will be reviewed as a cohort for this special issue. All submissions will go through the International Journal of Human Resource Management regular double-blind review process and follow the standard norms and processes.

For questions regarding the content of this special issue, please contact the guest editors:

Jeroen Meijerink, University of Twente; j.g.meijerink@utwente.nl

Mark Boons, Erasmus University Rotterdam; mboons@rsm.nl

Anne Keegan, University College Dublin; anne.keegan@ucd.ie

Janet Marler, State University of New York at Albany; jmarler@albany.edu

\section{References}

Bondarouk, T., Parry, E., \& Furtmueller, E. (2017). Electronic HRM: Four decades of research on adoption and consequences. The International Journal of Human Resource Management, 28(1), 98-131.

Boons, M., Stam, D., \& Barkema, H. G. (2015). Feelings of pride and respect as drivers of ongoing member activity on crowdsourcing platforms. Journal of Management studies, 52(6), 717-741.

Brynjolfsson, E., \& McAfee, A. (2014). The second machine age: Work, progress, and prosperity in a time of brilliant technologies. New York: W.W. Norton \& Company.

Chen, L., Mislove, A., \& Wilson, C. (2015). Peeking beneath the hood of uber. Paper presented at the Proceedings of the 2015 Internet Measurement Conference.

Colbert, A., Yee, N., \& George, G. (2016). The digital workforce and the workplace of the future. Academy of management Journal, 59(3), 731-739.

Coyle, D. (2017). Precarious and productive work in the digital economy. National Institute Economic Review, 240(1), R5-R14.

Davenport, T. H., \& Kirby, J. (2016). Only humans need apply: Winners and losers in the age of smart machines. New York: HarperCollins.

Fieseler, C., Bucher, E., \& Hoffmann, C. P. (in press). Unfairness by design? The perceived fairness of digital labor on crowdworking platforms. Journal of Business Ethics, 1-19.

Habraken, M., \& Bondarouk, T. (2017). Smart industry research in the field of HRM: Resetting job design as an example of upcoming challenges. In T. Bondarouk, $\mathrm{H}$. Ruel, \& E. Parry (Eds.), Electronic HRM in the smart era (pp. 221-259). Bingley: Emerald Publishing.

Hannon, J., Jelf, G., \& Brandes, D. (1996). Human resource information systems: operational issues and strategic considerations in a global environment. International Journal of Human Resource Management, 7(1), 245-269.

Kuhn, K. M., \& Maleki, A. (2017). Micro-entrepreneurs, Dependent contractors, and instaserfs: Understanding online labor platform workforces. The Academy of Management Perspectives, 31(3), 183-200.

Marler, J. H., \& Boudreau, J. W. (2017). An evidence-based review of HR analytics. The International Journal of Human Resource Management, 28(1), 3-26.

Marler, J. H., \& Fisher, S. L. (2013). An evidence-based review of e-HRM and strategic human resource management. Human Resource Management Review, 23(1), 18-36. 
Meijerink, J., Bondarouk, T., \& Maatman, M. (2013). Exploring and comparing HR shared services in subsidiaries of multinational corporations and indigenous organisations in the Netherlands: A strategic response analysis. European journal of international management, 7(4), 469-492.

Nakatsu, R. T., Grossman, E. B., \& Iacovou, C. L. (2014). A taxonomy of crowdsourcing based on task complexity. Journal of Information Science, 40(6), 823-834.

Ruël, H., Bondarouk, T., \& Looise, J. K. (2004). E-HRM: Innovation or irritation. An explorative empirical study in five large companies on web-based HRM. Management Revue, 15(3), 364-380.

Strohmeier, S. (2009). Concepts of e-HRM consequences: A categorisation, review and suggestion. The International Journal of Human Resource Management, 20(3), 528-543.

Strohmeier, S. (in press). Smart HRM - a Delphi study on the application and consequences of the Internet of Things in Human Resource Management. The International Journal of Human Resource Management, 1-30. 